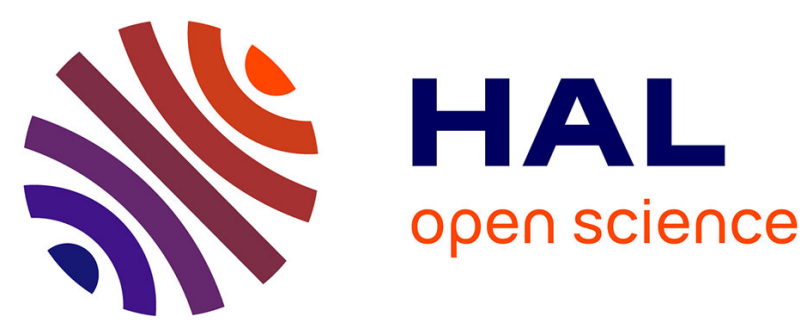

\title{
Effect of GA3 and paclobutrazol on adventitious shoot regeneration of two Pelargonium sp.
}

Latifa Hamama, Linda Voisine, Amani Naouar, R. Gala, Denis Cesbron, Gilles Michel, F. Leplat, Fabrice Foucher, Laurence Hibrand-Saint Oyant, Noëlle Dorion

\section{To cite this version:}

Latifa Hamama, Linda Voisine, Amani Naouar, R. Gala, Denis Cesbron, et al.. Effect of GA3 and paclobutrazol on adventitious shoot regeneration of two Pelargonium sp.. 7. ISHS on In Vitro Culture \& Horticultural Breeding, Sep 2011, Ghent, Belgium. pp.1. hal-01608780

\section{HAL Id: hal-01608780 \\ https://hal.science/hal-01608780}

Submitted on 6 Jun 2020

HAL is a multi-disciplinary open access archive for the deposit and dissemination of scientific research documents, whether they are published or not. The documents may come from teaching and research institutions in France or abroad, or from public or private research centers.
L'archive ouverte pluridisciplinaire HAL, est destinée au dépôt et à la diffusion de documents scientifiques de niveau recherche, publiés ou non, émanant des établissements d'enseignement et de recherche français ou étrangers, des laboratoires publics ou privés.

\section{다(1)(2)}

Distributed under a Creative Commons Attribution - ShareAlikel 4.0 International 


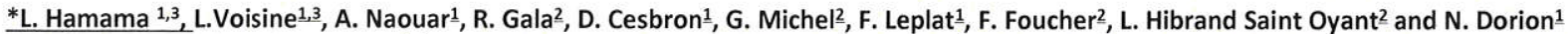

UMR GenHort A1259, IFR Quasav 149- (1) AGROCAMPUS OUEST Centre d'Angers - INHP, 2 rue Le Nôtre, 49045 Angers cedex 01, France - (2) Centre INRA Angers-Nantes, rue Georges Morel, 49071 Beaucouzé, France - (3) Université d'Angers, UFR Sciences, 2 bd Lavoisier 49045 Angers cedex 01, France.* latifa.hamama@agrocampus-ouest.fr

\section{OBJECTIVES}

In this study, we test the effect of gibberellic acid $\left(\mathrm{GA}_{3}\right)$ and Paclobutrazol (PBZ) on callus formation and adventitious shoot regeneration on Pelargonium sp., before using this species for functional validation of genes involved in the process of $G A$ regulation via genetic transformation.

\section{INTRODUCTION}

In vitro plant regeneration efficient methods are essential in biotechnology. Cell dedifferentiation and differentiation are complex phenomena induced in vitro by growth regulators. The effect of auxins and cytokinins are well known whereas the effect of gibberellins (GA) was less studied. However, Hutchinson et al., 1997 showed that GA $\mathrm{A}_{3}$ had an inhibitory effect on development of somatic embryogenesis in Pelargonium x hortorum. Conversely, paclobutrazol (PBZ), a GA biosynthetic inhibitor, promoted development of somatic embryogenesis.

$$
\text { MATERIAL AND METHODS }
$$

In a first experiment, adventitious shoot regeneration was performed on Pelargonium x hortorum 'Panaché sud' ('P.sud') and Pelargonium $x$ domesticum 'Autumn haze' ('P.dom') according to Hassanein and Dorion (2005). First, we evaluated the effect of a range of $\mathrm{GA}_{3}$ concentrations $(1-20 \mu \mathrm{M})$ and PBZ (0.1-1 $\left.\mu \mathrm{M}\right)$ on callus induction and bud regeneration. In a second experiment $\mathrm{GA}_{3}$ and $\mathrm{PBZ}$ were added to the regeneration medium (SRM) separately or together to check the relationship between PBZ and $G \mathrm{~A}_{3}$ effects.
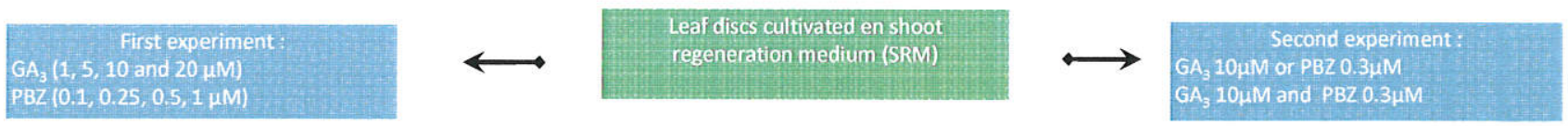

\section{RESULTS AND DISCUSSION}

Shoot regeneration process on SRM. On leaf discs arising from 4-5 weeks-old mother plant and containing petiole umbilicus both genotypes led to highly efficient formation of adventitious shoots (Table 1). 'P.dom' explants produced limited callus in the cut edges of leaf discs, buds were formed quickly and direct secondary organogenesis took place (Fig.1A). Conversely, 'P.sud' explants were totally dedifferentiated in callus which proliferated extensively before bud formation through several subcultures (Fig.2A).

Effect of $\mathrm{GA}_{3}$ on callus formation and shoot regeneration. In both cases, $G \mathrm{~A}_{3}$ applied alone (Fig.1B, 2B, Table 1), inhibited bud regeneration as soon as $5 \mu \mathrm{M}$ (Fig.3A). Similarly, the rate of callus formation (Fig.3B) decreased drastically when $5 \mu \mathrm{M} \mathrm{GA}{ }_{3}$ was applied to 'P.dom' explants while for 'P.sud', callus decreasing is less evident. Same results were observed by Hutchinson et al (1997), It is likely that $\mathrm{GA}_{3}$ inhibited the dedifferentiation level since callus is also inhibited.

Effect of PBZ on callus formation and shoot regeneration. On 'P.dom' explants, callus extended to the whole explant when PBZ was added to SRM (Fig. 1D, 1D'), Regeneration was not significantly promoted but the initiated buds had an early-onset and a better appearance provided that PBZ is applied in the early stages of cellular dedifferentiation. Similarly, for 'P.sud', which formed an abundant callus, PBZ did not improve regeneration (Table 1) and led to shoots of poor quality (hyperhydric)(Fig.2C). In our experiment, results on 'P. dom' confirmed more or less those of Hutchinson while 'P.sud' did not.
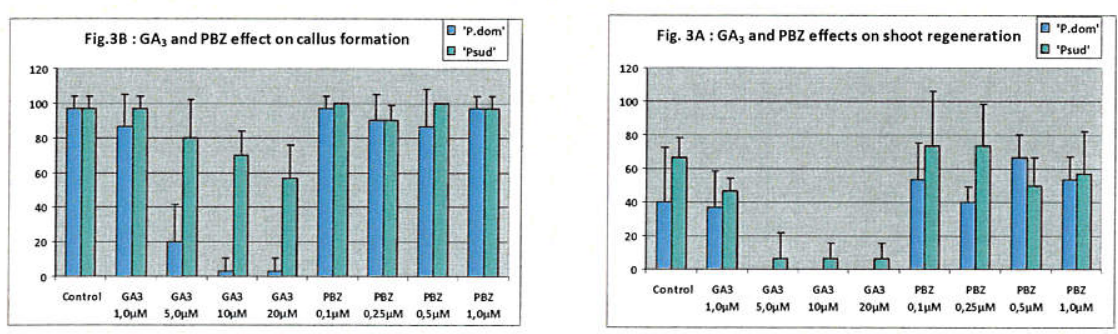

Table 1. Effect of $\mathrm{GA}_{3}, \mathrm{PBZ}$ or $\mathrm{GA}_{3}+\mathrm{PBZ}$ on callus formation and shoot regeneration

\begin{tabular}{|c|c|c|c|c|c|}
\hline \multicolumn{2}{|c|}{ Regeneration medium } & \multirow{2}{*}{$\begin{array}{c}\begin{array}{c}\text { SRM } \\
\text { control }\end{array} \\
94 \%\end{array}$} & \multirow{2}{*}{$\begin{array}{c}\begin{array}{c}\text { SRM } \\
\mathrm{GA}_{3} 10 \mu \mathrm{M}\end{array} \\
48 \%\end{array}$} & \multirow{2}{*}{ 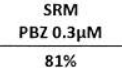 } & \multirow{2}{*}{$\begin{array}{c}\begin{array}{c}\mathrm{SRM} \\
\mathrm{GA} \\
\mathrm{GA}_{3}+\mathrm{PBZ}\end{array} \\
89 \%\end{array}$} \\
\hline 'P.dom' & Explants forming calli & & & & \\
\hline & Explants forming shoots & $65 \%$ & $7 \%$ & $44 \%$ & $13 \%$ \\
\hline & $\begin{array}{l}\text { regenerated shoots } \\
\text { (mean/explants) }\end{array}$ & $\begin{array}{c}53 \\
(14.0 \pm 7.4) \text { ab }\end{array}$ & $\begin{array}{c}4 \\
(0.2 \pm 0.4) a\end{array}$ & $\begin{array}{c}69 \\
(17.3 \pm 19.0) b\end{array}$ & $\begin{array}{c}9 \\
(2.3 \pm 4.5) \mathrm{a}\end{array}$ \\
\hline \multirow[t]{3}{*}{ 'P. sud' } & Explants forming calli & $100 \%$ & $97 \%$ & $100 \%$ & $94 \%$ \\
\hline & Explants forming shoots & $83 \%$ & $23 \%$ & $79 \%$ & $13 \%$ \\
\hline & $\begin{array}{l}\text { Regenerated shoots } \\
\text { (mean/explant) }\end{array}$ & $\begin{array}{c}296 \\
(59.2 \pm 36.2) b\end{array}$ & $\begin{array}{c}28 \\
(5.6 \pm 5.7) \text { a }\end{array}$ & $\begin{array}{c}304 \\
(60.8 \pm 30.5) \mathrm{b}\end{array}$ & $\begin{array}{c}9 \\
(1.8 \pm 4.0)\end{array}$ \\
\hline
\end{tabular}

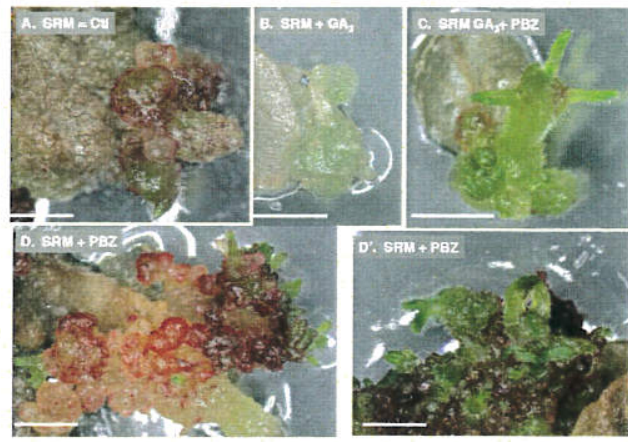

$\triangle$ Fig.1. Effect of $\mathrm{GA}_{3}$ and PBZ on 'P.dom' leaf discs.

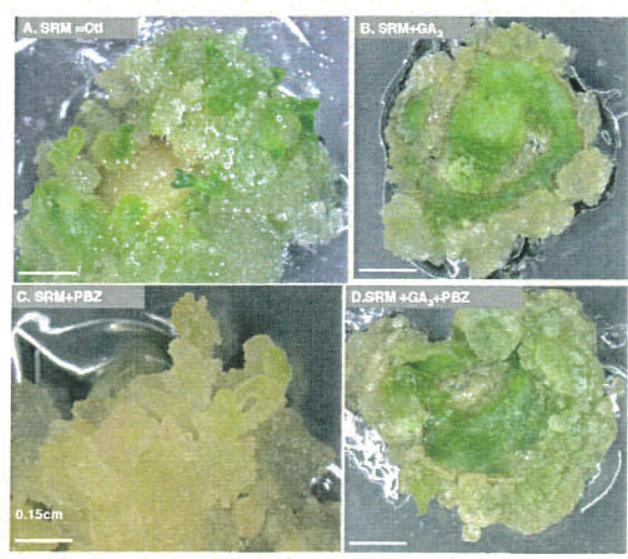

$\triangle$ Fig.2. Effect of $\mathrm{GA}_{3}$ and PBZ on 'P. sud' leaf discs.

Effect of PBZ + GA.$P B Z$ and $\mathrm{GA}_{3}$ applied at the same time (Table 1) restored totally the ability of callus formation compare to $\mathrm{GA}_{3}$ alone and therefore but to a lesser extend the regeneration process in 'P.dom'. Conversely, in 'P.sud' explants, no restoration of buds regeneration was observed. This last result was expected since PBZ is an inhibitor of GA's synthesis.

\section{CONCLUSION}

In the experiments we have found complex relationships between $\mathrm{GA}_{3}, \mathrm{PBZ}$ and dedifferentiation (callus) versus differentiation (shoot) processes within two cv of Pelargonium. The effect of GA's and its inhibitor varied according to the genotype and some of the effects differed from those observed by Hutchinson et al (1997). According to our results and in order to validate by transgenesis the function of gene related to GA's pathway, ' $P$. dom' which behaved better that 'P.sud' should be used. Moreover attention should be paid to the risk of regeneration inhibition when using overexpression of genes implied in $\mathrm{GA}_{3}$ synthesis.

Hassanein, A, Dorion, N, (2005). Efficient plant regeneration system from leaf discs of zonal (Pelargonium $x$ hortorum) and two scented (P. capitatum and $P$. graveolens) Geraniums. Plant Cell, Tissue and Organ Culture. 83: 231-240. Hutchinson, M.J., KrishnaRaj, S., Saxena, P.K., (1997). Inhibitory effect of $\mathrm{GA}_{3}$ on the development of thidiazuron-induced somatic embryogenesis in geranium (Pelargonium $\mathrm{x}$ hotorum Bailey) hypocotyls cultures. Plant Cell Reports.
16: 435-438; 


$$
\begin{aligned}
& 7^{\text {th }} \text { ISHS on in vitpo culture a Horticultural Breeding } \\
& \text { Ghent (Belgique) } 18-22 \text { sept. } 2011 \text {. }
\end{aligned}
$$

\title{
Effect of $\mathrm{GA}_{3}$ and paclobutrazol on adventitious shoot regeneration of two Pelargonium sp.
}

\author{
L. Hamama ${ }^{1,2}$, L.Voisine ${ }^{1,2}$, A. Naouar ${ }^{1}$, R. Gala ${ }^{3}$, D. Cesbron ${ }^{1}$, G. Michel ${ }^{3}$, F. Leplat ${ }^{1}$, F. Foucher ${ }^{3}$, L. Hibrand Saint \\ Oyant $^{3}$ and N. Dorion ${ }^{1}$.
}

UMR GenHort 1259, IFR149 QUASAV (Agrocampus-Ouest, INRA, Univ. Angers)

1. Agrocampus-Ouest centre d'Angers, 2 Rue Le Nôtre, 49045 Angers, France

2. Université Angers, 2 Bd Lavoisier, 49045 Angers Cedex 01 Angers, France

3. Centre INRA Angers-Nantes, 42 Rue Georges Morel, BP 60057, 49071 Beaucouzé Latifa.hamama@agrocampus-ouest.fr

\begin{abstract}
In vitro plant regeneration methods from differentiated tissues are essential in biotechnology (plant breeding, genetic transformation, functional validation of genes...). Cell dedifferentiation and differentiation are complex phenomena induced in vitro by growth regulators. The effect of auxins and cytokinins has been extensively studied on somatic embryogenesis and organogenesis for several plants species. The effect of gibberellins (GA) is much less studied.

Hutchinson et al., 1997 showed that $\mathrm{GA}_{3}$ has an inhibitory effect on development of somatic embryogenesis in Pelargonium $x$ hortorum. Conversely, paclobutrazol, a GA biosynthestic inhibitor, promotes development of somatic embryogenesis

The objectives of this study was to test the effect of $\mathrm{GA}_{3}$ and paclobutrazol on adventitious shoot regeneration

Adventitious shoot regeneration was performed on two Pelargonium species, Pelargonium $\mathrm{x}$ hortorum Panaché sud 'P.sud' and Pelargonium domesticum Autumn haze 'P.dom' according in the first step to Hassanein and Dorion 2005.

By choosing the explant type and mother plant age, both genotypes led to the highly efficient formation of adventitious shoots $(>70 \%)$ on the same medium. Both genotypes have different behavior during the shoot regeneration. 'P.dom' explants produces limited callus in the cut edges of leaf discs, buds are formed quickly and direct secondary organogenesis took place. 'P.sud' explants are totally dedifferentiated in callus which proliferates extensively before bud formation through several subcultures.

We evaluated the effect of a concentration range of $\mathrm{GA}_{3}(1-20 \mu \mathrm{M})$ and paclobutrazol $(0.1-3 \mu \mathrm{M})$ on the callus induction and bud regeneration of the two genotypes. $\mathrm{GA}_{3}$ and paclobutrazol were added in regeneration medium separately or together to check, in the latter case, if the paclobutrazol can restore $\mathrm{GA}_{3}$ effect.

In both cases, $\mathrm{GA}_{3}$ applied alone, completely inhibits the bud regeneration. Moreover, the rate of callus formation decreased by $50 \%$ when $1 \mu \mathrm{M} \mathrm{GA}_{3}$ was applied to 'P.dom' explants. The same result was obtained on 'P.sud' explants using $20 \mu \mathrm{M} \mathrm{GA}_{3}$. Paclobutrazol $(3 \mu \mathrm{M})$ applied at the same time that $\mathrm{GA}_{3}(10 \mu \mathrm{M})$ can partially restore regeneration process.

In ' $P$. dom', the use of paclobutrazol alone led to increase callus formation and slightly improved the rate of regeneration. Initiated buds have a better appearance (less hyperhydricity) provided that paclobutrazol is applied only in the early stages of cellular dedifferentiation. For genotype 'P. sud', which forms an abundant callus, paclobutrazol does not improve regeneration and led to hyperhydric shoot formation.

The understanding of gibberellins role on adventitious shoot regeneration in Pelargonium sp., is needed in order to improve the procedure. The modalities of cell differentiation and bud regeneration through callus or not are probably of major importance.
\end{abstract}

Keywords: Adventitious shoots regeneration; $\mathrm{GA}_{3}$; Paclobutrazol; Pelargonium.

\section{References}

Hassanein, A, Dorion, N, (2005). Efficient plant regeneration system from leaf discs of zonal (Pelargonium $\mathrm{x}$ hortorum) and two scented (P. capitatum and P. graveolens) Geraniums. Plant Cell, Tissue and Organ Culture. 83: 231-240.

Hutchinson, M.J., KrishnaRaj, S., Saxena, P.K., (1997). Inhibitory effect of GA3 on the development of thidiazuron-induced somatic embryogenesis in geranium (Pelargonium x hotorum Bailey) hypocotyls cultures. Plant Cell Reports. 16: 435-438. 